\title{
LAVANDULA OFFICINALIS UNTUK AROMATERAPI DENGAN TEKNIK BOWLING DAN PENGARUHNYA TERHADAP PENURUNAN NYERI KEHAMILAN TRIMESTER II DAN III
}

\author{
Ari Christiana, Tri Utami P. \\ ch ari@ymail.com
}

Prodi Kebidanan STIKES Widyagama Husada

\begin{abstract}
ABSTRAC
In pregnancy, mothers often has stomach cramp. This condition is normal and generally, but is not really dangerous. But it can not allowed to happen until feel the pain. Medically, stomach cramp is a contraction in pregnancy, it is physiologies reaction from uterus periodically because the uterus contents of fetus. The contraction is felt from second trimester and generally it is hapenned once. One way in increasing the painful is lavender aromatherapy. From the previous research, it is said that lavender is used to decrease the cholera. This research is done to know the effect of lavender in decreasing the stomach painful of pregnant women.

The research design is pre experimental with pre-post test design. The research population is pregnant women in second and third trimester which feel painful in pregnancy and they are being the sample. First the respondents are observed the intensity of stomach painful before they are given the lavender aromatherapy and it is observed again after they are given aromatherapy with bowling technique for about 20 minutes. The research result is analyzed by paired $t$-test.

The analyze result paired $t$-test is got $p=0.000<0.05$, the conclusion is $H_{1}$ is accepted. It means there is an effect of lavender aromatherapy in decreasing stomach painful of pregnant women on the second and third trimester. For the health workers, especially midwives is hoped to give the health education and apply the lavender aromatherapy for pregnant women as one alternative in decreasing stomach painful cramp as long as their pregnancy.
\end{abstract}

Keywords : Lavender aromatherapy, Stomach painful pains of second and third trimester 


\begin{abstract}
ABSTRAK
Saat hamil terkadang muncul kram di sekitar daerah perut. Hal ini normal dan umumnya tidak berbahaya, tapi bukan berarti boleh dibiarkan sampai menimbulkan rasa sakit berkepanjangan. Secara medis, kram perut adalah kontraksi dalam kehamilan, yakni reaksi fisiologis dari rahim secara periodik karena rahim berisi janin yang hidup. Kontraksi mulai dirasakan sejak trimester 2 kehamilan dan umumnya terjadi sesekali saja. Salah satu cara dalam mengurangi nyeri akibat kram adalah armoterapi lavender. Dari penelitian disebutkan bahwa aromaterapi lavender bermanfaat untuk menurunkan nyeri pada penyakit colera. Tujuan penelitian ini untuk mengetahui pengaruh aromaterapi lavender dalam mengurangi nyeri perut pada ibu hamil.

Desain penelitian yang digunakan adalah pre eksperimental dengan pre-post test design. Populasi dalam penelitian ini adalah seluruh ibu hamil trimester II dan III yang mengalami nyeri pada kehamilan dan seluruhnya dijadikan sampel. Responden awalnya diamati intensitas nyeri perut sebelum diberikan aromateraphy lavender dan diamati lagi intensitas nyeri perut setelah diberikan aromaterapi lavender dengan teknik bowling selama 20 menit. Hasil penelitian kemudian dianalisis dengan Paired TTest.

Hasil analisa Paired T-Test didapatkan $p=0.000<0.05$, kesimpulannya $H_{a}$ diterima yang berarti ada pengaruh pemberian aromaterapi lavender terhadap penurunan tingkat nyeri perut ibu hamil trimester II dan III. Bagi tenaga kesehatan khususnya profesi bidan diharapkan untuk memberikan pendidikan kesehatan dan menerapkan pemberian aromaterapi lavender kepada ibu hamil sebagai salah satu alternatif non farmakologi dalam mengurangi nyeri perut akibat kram saat kehamilan.
\end{abstract}

Kata kunci : Aromaterapi Lavender, Nyeri perut Kehamilan Trimester II dan III

\section{PENDAHULUAN}

Kehamilan merupakan proses yang fisiologis dan alamiah, proses kehamilan merupakan satu kesatuan mata rantai mulai dari konsepsi, nidasi, adaptasi ibu terhadap nidasi, pemeliharaan kehamilan, perubahan hormon sebagai persiapan menyongsong kelahiran bayi (Manuaba, 2007). Kehamilan melibatkan berbagai perubahan fisiologis antara lain perubahan fisik tubuh, perubahan sistem pencernaan, sistem respirasi, sistem traktus urinarius, sirkulasi darah. Kehamilan pada umumnya berkembang dengan normal, namun kadang tidak sesuai dengan yang diharapkan, sulit diprekdiksi apakah ibu hamil akan bermasalah selama kehamilan ataupun baik-baik saja (Sarwono, 2006).

Saat hamil keluhan yang sering muncul salah satunya rasa keras dan nyeri disekitar daerah perut, dibeberapa bulan kedepan kehamilan, ada juga beberapa wanita yang tidak mengalami rasa kram pada kehamilan. Hal ini biasanya terjadi pada ibu hamil dan umumnya tidak membahayakan, meski demikian tak berarti boleh dibiarkan sampai menimbulkan rasa sakit berkepanjangan. Rasa kram timbul disebabkan oleh gangguan asupan oksigen ke rahim, pertumbuhan dan pembesaran dari rahim, meningkatnya hormon progesterone dan relaxin, implantasi serta stress. Keluhan ini biasanya timbul sebelum bulan-bulan awal kehamilan dan normalnya akan hilang pada usia kehamilan 10-12 minggu (Dwi, 2009). Rasa nyeri tersebut sebenarnya adalah hal yang fisiologis. Seharusnya ibu dapat rileks, nyaman dan bahagia dalam masamasa ini, tapi sejauh ini rasa nyeri tersebut menjadi masalah utama sehingga ibu sering merasa takut (Bobak, 2004).

Secara umum telah diterima bahwa kehamilan membawa resiko bagi ibu. Menurut WHO (Profil Pusdiknakes, 2003) sekitar $15 \%$ dari seluruh ibu hamil akan berkembang menjadi komplikasi yang berkaitan dengan kehamilannya serta dapat mengancam jiwa ibu dan bayi (Sugiri, 2003). Dari 5 juta kehamilan yang terjadi di Indonesia setiap tahunnya, diperkirakan 20.000 ibu meninggal akibat komplikasi 
kehamilan, $8 \%$ diantaranya disebabkan nyeri pada kehamilan. Di Sumatera Utara ibu hamil yang meninggal dunia akibat komplikasi kehamilan lebih dari 50 orang dari 19.500 ibu hamil. 20-30\% wanita hamil mengalami perdarahan atau nyeri 1 kali selama 20 minggu pertama kehamilan. Sekitar separuhnya menyebabkan keguguran, 85\% keguguran terjadi pada minggu ke 13-20, dua pertiganya terjadi akibat kelainan pada ibu dan sepertiganya penyebabnya tidak diketahui, sebelum terjadinya keguguran wanita hamil rahimnya berkontraksi yang menyebabkan nyeri pada perut (Sugiri,2007).

Salah satu cara dalam mengurangi nyeri akibat kram adalah aromaterapi lavender. Aromaterapi adalah metode pengobatan untuk merevitalisasi (menggiatkan kembali) dan meregulasi (mengatur) kinerja organ-organ tubuh dengan menggunakan minyak esensial dari tumbuh-tumbuhan beraroma. Manfaatnya antara lain melancarkan sirkulasi darah, meringankan beberapa keluhan yang kerap timbul selama hamil dan membantu melancarkan proses persalinan. Bau-bauan tersebut mempengaruhi bagian otak yang berkaitan dengan mood (suasana hati), emosi, ingatan dan pembelajaran. Sedangkan untuk minyak lavender sendiri diketahui memiliki sifat analgesik dan anti-inflamasi serta sifat menenangkan (Hutasoid, 2005).

Menurut Dean (2007) lavender adalah salah satu dari minyak yang paling umum digunakan untuk mengobati stress dan menenangkan emosi. Kata lavender berasal dari kata latin artinya mencuci. Lavender juga digunakan dalam ruang melahirkan untuk melahirkan untuk menyambut bayi dan menenangkan sang ibu serta menurunkan rasa nyeri persalinan. Lavender dapat digunakan dengan berbagai cara yaitu, berendam, dihirup, pijat, semprot dan dibakar.

Dari penelitian disebutkan bahwa lavender bermanfaat sebagai aromaterapi untuk menurunkan nyeri pada penyakit colera di Inggris juga lavender efektif mengobati depresi, kecemasan, peradangan dan stress ringan (Phytomedicine, 2012). Dari sebuah penelitian lain didapatkan hasil bahwa pada ibu hamil dengan usia kehamilan > 38 minggu di dapatkan hasil bahwa pijat aromaterapi lavender dapat mengurangi nyeri yang dikeluhkan oleh ibu hamil tersebut (Int J Nurs Pract. 2012).

Dari uraian latar belakang tersebut, dapat dirumuskan masalah penelitian ini adalah adakah pengaruh penggunaan aromaterapi lavender untuk mengurangi nyeri perut pada ibu hamil trimester II dan III.

Penelitian ini bertujuan :

1. Mengidentifikasi tingkat nyeri perut pada ibu hamil sebelum diberikan aromaterapi lavender pada ibu hamil trimester II dan III.

2. Mengidentifikasi tingkat nyeri perut pada ibu hamil sesudah diberikan aromaterapi lavender pada ibu hamil trimester II dan III.

3. Menganalisis pengaruh pemberian aromaterapi lavender terhadap penurunan tingkat nyeri perut pada ibu hamil trimester II dan III.

\section{METODE PENELITIAN}

Penelitian ini adalah pre eksperimental dengan pre test - post test design. Populasi dalam penelitian ini adalah seluruh ibu hamil trimester II dan III yang mengalami nyeri perut pada kehamilan trimester II dan III di BPS Ny.S pada bulan Juli - Agustus 2012 yang seluruhnya dijadikan sampel. Data diambil langsung dengan teknik wawancara dan lembar observasi yang berisi alat ukur nyeri pada kehamilan. Sebelumnya peneliti memberikan penjelasan dimana responden bisa memilih atau menunjukkan skor nyeri dengan ketentuan $0=$ tidak nyeri, 1-3=nyeri ringan, 4$6=$ nyeri sedang, $7-10=$ nyeri berat. Lembar observasi ini diberikan kepada responden dengan syarat sebelumnya responden mendatangani informed consent. Responden 
awalnya diamati intensitas nyeri perut sebelum diberikan aromateraphy lavender dan diamati lagi intensitas nyeri perut setelah diberikan aromaterapi lavender dengan teknik bowling selama 20 menit. Hasil penelitian kemudian dianalisis dengan Paired T-Test.

Tabel 1 Variabel Penelitian

\begin{tabular}{|c|c|c|c|c|}
\hline Variabel & Definisi Operasional & Alat Ukur & Skala & Kategori \\
\hline $\begin{array}{l}\text { Nyeri } \\
\text { kehamilan } \\
\text { sebelum dan } \\
\text { setelah } \\
\text { perlakuan }\end{array}$ & $\begin{array}{l}\text { Nyeri kehamilan yang } \\
\text { dirasakan ibu sebelum } \\
\text { dan setelah diberikan } \\
\text { aromaterapi lavender }\end{array}$ & $\begin{array}{l}\text { Pengamatan / skala } \\
\text { ukur (VDS) }\end{array}$ & Interval & $\begin{array}{l}\text { Menurut skala } \\
\text { VDS } \\
0=\text { tidak nyeri } \\
1-3=\text { nyeri ringan } \\
4-6=\text { nyeri sedang } \\
7-10=\text { nyeri berat }\end{array}$ \\
\hline $\begin{array}{l}\text { Pemberian } \\
\text { aromaterapi } \\
\text { lavender }\end{array}$ & $\begin{array}{l}\text { Kegiatan memberikan } \\
\text { aromaterapi lavender } \\
\text { pada ibu hamil yang } \\
\text { mengalami nyeri perut } \\
\text { pada kehamilan trimester } \\
\text { II dan III. }\end{array}$ & Kuesioner & Nominal & \\
\hline
\end{tabular}

\section{HASIL PENELITIAN}

Tabel 2 tingkat nyeri responden sebelum diberikan aromaterapi lavender

\begin{tabular}{ccc}
\hline Sebelum Terapi & Frekuensi (f) & Prosentase (\%) \\
\hline Tidak Nyeri & 0 & 0 \\
Nyeri Ringan & 0 & 0 \\
Nyeri Sedang & 7 & 30 \\
Nyeri Berat & 13 & 70 \\
\hline Total & 20 & 100 \\
\hline
\end{tabular}

Pada Tabel 2 tingkat nyeri sebelum diberikan aromaterapi lavender didapatkan $30 \%$ responden mengalami nyeri sedang, $70 \%$ responden mengalami nyeri berat.

Tabel 3 tingkat nyeri responden sesudah diberikan aromaterapi lavender

\begin{tabular}{ccc}
\hline Sesudah Terapi & Frekuensi (f) & Prosentase (\%) \\
\hline Tidak Nyeri & 0 & 0 \\
Nyeri Ringan & 7 & 40 \\
Nyeri Sedang & 13 & 60 \\
Nyeri Berat & 0 & 0 \\
\hline Total & 20 & 100 \\
\hline
\end{tabular}

Pada Tabel 3 Didapatkan data tingkat nyeri sesudah diberikan aromaterapi lavender didapatkan $60 \%$ responden mengalami nyeri sedang, $40 \%$ responden mengalami nyeri ringan. 
Tabel 4 Tabulasi Silang antara usia responden dengan tingkat nyeri sebelum diberikan aromaterapi lavender.

\begin{tabular}{llllll}
\hline Usia & Tidak Nyeri & Nyeri Ringan & Nyeri Sedang & Nyeri Berat & Total \\
\hline$<20$ tahun & $0(0 \%)$ & $0(0 \%)$ & $2(13,3 \%)$ & $13(86,7 \%)$ & $15(100 \%)$ \\
$20-35$ tahun & $0(0 \%)$ & $0(0 \%)$ & $5(100 \%)$ & $0(0 \%)$ & $5(100 \%)$ \\
$>35$ tahun & $0(0 \%)$ & $0(0 \%)$ & $0(0 \%)$ & $0(0 \%)$ & $0(0 \%)$
\end{tabular}

Berdasarkan tabel 4 diperoleh data bahwa usia $<20$ tahun yang merasakan nyeri $13,3 \%$. Sedangkan usia 25-35 tahun keseluruhan responden merasakan nyeri sedang $100 \%$.

berat sebanyak $86,7 \%$ dan yang nyeri sedang

Tabel 5 Tabulasi Silang antara usia responden dengan tingkat nyeri sesudah diberikan aromaterapi lavender.

\begin{tabular}{llllll}
\hline Usia & Tidak Nyeri & Nyeri Ringan & Nyeri Sedang & Nyeri Berat & Total \\
\hline$<20$ tahun & $0(0 \%)$ & $2(13,3 \%)$ & $13(86,7 \%)$ & $13(86,7 \%)$ & $15(100 \%)$ \\
$20-35$ tahun & $0(0 \%)$ & $4(80 \%)$ & $1(20 \%)$ & $0(0 \%)$ & $5(100 \%)$ \\
$>35$ tahun & $0(0 \%)$ & $0(0 \%)$ & $0(0 \%)$ & $0(0 \%)$ & $0(0 \%)$
\end{tabular}

Berdasarkan tabel 5 diperoleh data bahwa usia $<20$ tahun yang merasakan nyeri ringan $13,3 \%$ sebanyak dan yang nyeri

Tabel 6 tabulasi silang antara gravida dengan tingkat nyeri sebelum diberikan aromaterapi lavender.

\begin{tabular}{llllll}
\hline Gravida & Tidak Nyeri & Nyeri Ringan & Nyeri Sedang & Nyeri Berat & Total \\
\hline Primigravida & $0(0 \%)$ & $0(0 \%)$ & $2(13,3 \%)$ & $13(86,7 \%)$ & $15(100 \%)$ \\
Multigravida & $0(0 \%)$ & $0(0 \%)$ & $5(100 \%)$ & $0(0 \%)$ & $5(100 \%)$
\end{tabular}

Berdasarkan tabel 6 diperoleh data primigravida yang merasakan nyeri sedang sebanyak $13,3 \%$ dan yang nyeri berat $86,7 \%$ Sedangkan responden multigravida seluruhnya merasakan nyeri sedang $100 \%$.

Tabel 7 tabulasi silang antara gravida dengan tingkat nyeri setelah diberikan aromaterapi lavender.

\begin{tabular}{lll}
\hline Gravida & Tidak Nyeri & Nyeri Ringan \\
\hline Primigravida & $0(0 \%)$ & $3(20 \%)$ \\
Multigravida & $0(0 \%)$ & $4(80 \%)$
\end{tabular}

Berdasarkan tabel 7 diperoleh data primigravida yang merasakan nyeri ringan sebanyak $20 \%$ dan yang nyeri sedang $80 \%$. Sedangkan multigravida yang merasakan nyeri ringan $20 \%$ dan nyeri sedang $20 \%$.

\section{PEMBAHASAN}

sedang $86,7 \%$ Sedangkan usia 25-35 tahun sedang $20 \%$

Pada tabel 4 didapatkan hasil prosentase nyeri ibu hamil sebelum dilakukan terapi aromaterapi lavender adalah data bahwa usia $<20$ tahun yang merasakan nyeri berat sebanyak $86,7 \%$ dan yang nyeri sedang $13,3 \%$. Sedangkan usia $25-35$ tahun yang merasakan nyeri sedang $100 \%$. Tingkat nyeri pada ibu hamil di karenakan persepsi ibu Nyngri Skdnangg Negent Benaengentiỏtal proses

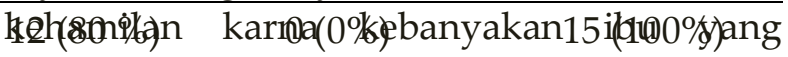

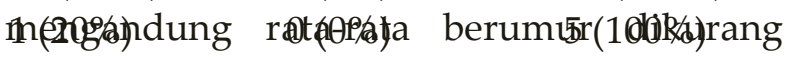
dari 20 tahun.(Kuswandi, 2003). Usia juga dapat menyebabkan nyeri pada ibu hamil trimester II dan III, Wintrobe (2003) menyatakan bahwa usia ibu dapat mempengaruhi timbulnya nyeri pada kehamilan, yaitu semakin rendah usia ibu hamil maka semakin berpontesi mengalami nyeri pada kehamilan. Frekuensi terbesar yang merasakan nyeri ringan $80 \%$ dan nyeri 
yang dialami oleh ibu hamil adalah nyeri berat.

Aromaterapi adalah terapi menggunakan minyak atsiri atau sari minyak dengan mekanisme kerja merangsang gelombang alfa pada otak sehingga menimbulkan efek ketenangan dan kenyamanan. Aromaterapi digunakan untuk menghilangkan nyeri, perawatan untuk kulit, mengurangi ketegangan dan kelelahan dan memperkuat seluruh tubuh. Ketika dihirup, mereka berkerja pada otak dan sistem saraf melalui stimulasi dan saraf penciuman (Dean, 2007).

Lavender adalah aromatik mumi yang diekstrak dari tanaman dengan sifat terapeutik, psikologis dan fisiologis yang khas, yang meningkatkan dan mencegah penyakit. Sifat lain dari minyak essensial yang dapat dimanfaatkan dalam aromaterapi adalah stimulasi, relaksasi, perbaikan pencernaan, dan sifat diuretic (pendorong produksi air seni). Hal ini banyak digunakan dirumah, klinik dan rumah sakit untuk berbagai keperluan seperti rasa sakit bagi wanita saat nyeri perut dan nyeri persalinan, menghilangkan rasa sakit yang disebabkan oleh efek samping dari kemoterapi pasien kanker dan rehabilitas pasien jantung (aromateraphy-essential.com, 2011).

Pada tabel 5 didapatkan hasil prosentase nyeri ibu hamil sesudah dilakukan latihan terapi aromaterapi lavender berdasarkan usia responden didapatkan data bahwa usia $<20$ tahun yang merasakan nyeri ringan $13,3 \%$ dan yang nyeri sedang $86,7 \%$ Sedangkan usia 25-35 tahun yang merasakan nyeri ringan $80 \%$ dan nyeri sedang $20 \%$. Hal ini menunjukkan penurunan tingkat nyeri pada ibu hamil setelah dilakukan terapi aromaterapi lavender.

Selain usia peneliti juga mengidentifikasi tingkat nyeri berdasarkan gravida. Dari tabel 6 pada primigravida didapatkan hasil 2 responden (13,3\%) mengalami nyeri sedang dan 13 responden $(86,7 \%)$ mengalami nyeri berat, dibandingkan multigravida tidak ada yang mengalami nyeri berat hanya 5 responden (100\%) mengalami nyeri sedang. Hal ini sesuai dengan teori (Muhardi,2001) disebutkan bahwa primigravida cenderung mengalami nyeri yang lebih berat daripada multigravida. Dari data tersebut disebabkan karena primigravida mempunyai nyeri yang lebih tinggi dan keragu-raguan pengalaman dalam kehamilan maupun persalinan. Dengan alasan tersebut hendaknya tenaga kesehatan lebih meningkatkan pemberian penyuluhan dan informasi tentang nyeri kehamilan maupun persalinan terutama bagi primigravida.

Tingkat nyeri ibu hamil sesudah dilakukan terapi aromaterapi lavender berdasarkan gravida (tabel 7) adalah: primigravida yang telah diberi aromaterapi lavender yang awalnya nyeri berat $13(86,7 \%)$ dan nyeri sedang $2(13,3 \%)$ menjadi nyeri ringan $3(20 \%)$ dan nyeri sedang sebanyak 12 (80\%). Sedangkan pada multigravida yang telah diberi aromateraphy lavender yang awalnya nyeri sedang 5 (100\%) menjadi nyeri ringan $4(80 \%)$ dan nyeri sedang 1 (20\%). Hal ini terlihat perubahan penurunan tingkat nyeri pada kehamilan trimester II dan III.

Menurut Anonimous (2010). Penurunan tingkat nyeri ini dikarenakan teknik ini mempunyai cara kerja dengan membawa kerja otak pada gelombang alfa yaitu gelombang yang memiliki frekuensi 14-30 HZ. Pada kondisi ini otak dalam keadaan relaks, santai, saat tubuh mulai mengeluarkan hormon serotonin dan endorfin. Hal ini terjadi karena terdapat beberapa faktor yang mempengaruhi tingkat nyeri ibu hamil yang sulit dikendalikan oleh peneliti misalnya keadaan psikologis ibu, kesiapan untuk menjadi ibu hamil tidak hanya dituntut kesiapan secara fisik, namun juga mental. Karena sedikit banyak hal tersebut berguna untuk mempersiapkan diri dalam datangnya gejala-gejala perubahan fisik tubuh yang mempengaruhi kondisi kejiwaan sang calon ibu. Umumnya banyak perubahan yang terjadi secara fisik pada ibu 
hamil. Seperti perubahan bentuk tubuh dengan badan yang semakin membesar, munculnya jerawat di wajah atau kulit muka yang mengelupas dan nyeri yang terjadi pada kehamilan. Namun satu hal yang pasti, perubahan secara mental pada ibu hamil sangat sulit ditebak dan tidak selalu sama terjadinya pada satu sama lain ibu hamil ataupun pada setiap kehamilan

Dalam penelitian ini diketahui bahwa terdapat pengaruh yang signifikan dengan pemberian terapi aromaterapi lavender pada ibu hamil. Hal ini dapat diketahui dari hasil analisa SPSS dengan uji statistik T-Test, didapatkan hal $p=0,000$. Untuk mengetahui adanya pengaruh terapi aromaterapi lavender terhadap penurunan tingkat nyeri pada ibu hamil trimester II dan III, maka dilakukan pengujian hipotesa penelitian dengan menggunakan Paired $T$ Test dengan bantuan SPSS dengan nilai $\alpha<0,05$. Analisa dilakukan dengan membandingkan antara tingkat nyeri sebelum dan sesudah diberikan terapi aromaterapi lavender. Dari hasil uji Paired T Test, didapatkan $p=0.000<0.05$. Sehingga kesimpulannya $\mathrm{H}_{a}$ diterima yang berarti ada pengaruh pemberian terapi aromaterapi lavender terhadap penurunan tingkat nyeri ibu hamil trimester II dan III.

Adanya pengaruh relaksasi terhadap tingkat nyeri dapat di jelaskan dengan teori dan cara kerja aromaterapi lavender. Metode relaksasi ini membantu memusatkan perhatian berdasarkan pada keyakinan bahwa perempuan dapat mengalami kehamilan dan persalinan melalui insting untuk melahirkan secara alami dengan tenang, nyaman, percaya diri. Terapi ini mengajarkan ibu hamil menjalankan teknik relaksasi yang alami, sehingga tubuh dapat bekerja dengan seluruh syaraf secara harmonis dan dengan kerjasama penuh. Terapi yang dilakukan secara teratur dan konsentrasi akan menyebabkan kondisi rileks pada tubuh sehingga tubuh memberikan respon untuk mengeluarkan hormon endorfin yang membuat ibu menjadi rileks dan menurunkan rasa nyeri terutama ketika otak mencapai gelombang alfa atau saat istirahat. Pada kondisi ini saat tubuh mengeluarkan hormon serotonin dan endorfin sehingga manusia dalam kondisi rileks tanpa ketegangan dan kecemasan (workbook pelatihan basic hypnosis dan hypnobirthing, 2010).

Penelitian ini sejalan dengan penelitian sebelumnya yang menyebutkan bahwa lavender bermanfaat aromaterapi untuk menurunkan nyeri pada penyakit colera di Inggris juga lavender efektif mengobati depresi, kecemasan, peradangan dan stress ringan (Phytomedicine, 2012) juga penelitian lain didapatkan hasil bahwa pada ibu hamil dengan usia kehamilan $>38$ minggu di dapatkan hasil bahwa pijat aromaterapi lavender dapat mengurangi nyeri yang dikeluhkan oleh ibu hamil tersebut (Int J Nurs Pract. 2012).

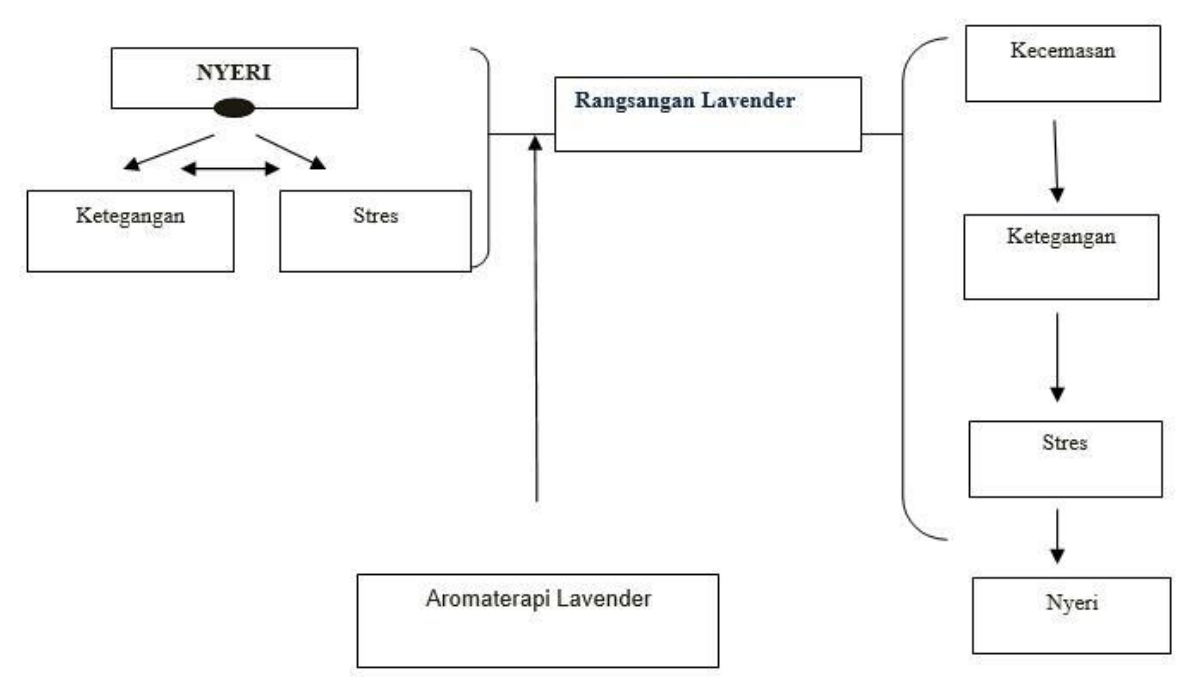


Gambar 1 Efektifitas Pemberian Aromaterapi Lavender dengan Nyeri Kehamilan.

\section{KESIMPULAN}

Berdasarkan hasil penelitian Lavender (Lavandula officinalis) untuk Aromaterapi dengan Teknik Bowling dan Pengaruhnya terhadap Penurunan Nyeri Kehamilan Trimester II dan III, dapat disimpulkan sebagai berikut :

1. Sebelum dilakukan terapi aromaterapi liavender diketahui bahwa 30\% responden mengalami nyeri sedang dan $70 \%$ responden mengalami nyeri berat.

2. Setelah dilakukan terapi aromaterapi lavender didapatkan $60 \%$ responden mengalami nyeri sedang, $40 \%$ responden mengalami nyeri ringan.

3. Berdasarkan hasil analisis Paired T-Test menunjukkan ada pengaruh pemberian terapi aromaterapi lavender terhadap tingkat nyeri perut ibu hamil trimester II dan III dengan tingkat signifikasi $p=$ 0.000

\section{DAFTAR PUSTAKA}

Anonimous, 2010. Metode Penelitian Hypnobirthing. Jakarta: Salemba Medika

Bobak, 2004. Pelatihan Klinik Asuhan Kebidanan, Jaringan Nasional Pelatihan Klinik-Kesehatan Reproduksi. Jakarta, JNPK-KR

Çetinkaya B, Başbakkal Z. 2012. Effectiveness of aromatherapy massage using lavender oil as a treatment for infantile colic. Int J
Nurs Pract. 2012 Apr;18(2):164-9. doi: 10.1111/j.1440-172X.2012.02015.x.

Dean, 2007. Buku Panduan Praktis Pelayanan Kesehatan Maternal dan Neonatal. Jakarta:YBPSP

Dwi, 2009. Asuhan Kebidanan. Jakarta : Salemba Medika

Essential-oil, 2011. Metode Aromateraphy Lavender. Goggle.com

Hritcu L, Cioanca O, Hancianu M. 2012. Effects of lavender oil inhalation on improving scopolamine-induced spatial memory impairment in laboratory rats. Phytomedicine. 2012 Apr 15;19(6):52934. doi: 10.1016/j.phymed.2012.02.002. Epub 2012 Mar 6.

Hutasoid, 2005. Ilmu Kebidanan Jakarta:EGC

Manuaba, 2007. Kesehatan Ibu Dan Anak. Salemba : Jakarta

Muhardi, 2001. Sinopsis obstetri Fisiolgi Patologi. EGC : Jakarta

Profil Pusdiknas, 2003. AKI dan AKB.

Sarwono, 2006. Ilmu Kebidanan. Rineka Cipta : Jakarta

Sugiri, 2003. Ilmu Kebidanan. EGC : Jakarta

Sugiri, 2007. Ilmu Kebidanan Jilid 1. EGC : Jakarta

Wintrobe, 2003. Ilmu Kandungan. Arcan : Jakarta

Workbook Pelatihan Bacic Hypnosis Dan Hypnobirthing, 2011 